\title{
Factors affecting in the use of antihipertension drugs with the health belief model approach in Puskesmas Pandanwangi Malang
}

Ika Ratna Hidayati ${ }^{[1]^{*}}$, Cikita Putri ${ }^{[1]}$

1 Department of Pharmacy, Faculty of Health Science, University of Muhammadiyah Malang, Malang, Indonesia Email: i.ratna80@gmail.com Phone: (+62) 851-0213-9869

\begin{tabular}{|c|c|}
\hline ARTICLE INFO & ABSTRACT \\
\hline $\begin{array}{l}\text { Article History } \\
\text { Received November 22, } 2019 \\
\text { Revised December 26, } 2019 \\
\text { Accepted January 7, } 2020 \\
\text { Keywords } \\
\text { Health belief model } \\
\text { Obedience } \\
\text { Captopril } \\
\text { Amlodipine } \\
\text { Doi } \\
\text { 10.22219/farmasains.v4i2.10071 }\end{array}$ & $\begin{array}{l}\text { Hypertension is a condition where systolic blood pressure is } 140 \mathrm{mmHg} \text { or } \\
\text { higher, and diastolic blood pressure is } 90 \mathrm{mmHg} \text { or higher. Generally, } \\
\text { hypertension patients use captopril and amlodipine as treatment of } \\
\text { hypertension. It is necessary to take various efforts to improve the } \\
\text { obedience of hypertensive patients during drug therapy. One theory } \\
\text { studies that obedience behavior is the Health Belief Model. The HBM } \\
\text { theory covers perceived susceptibility, severity, benefits, and barrier, along } \\
\text { with self-efficacy. To investigate factors affecting the obedience of } \\
\text { hypertensive patients during the antihypertensive captopril and } \\
\text { amlodipine medications treatment in the Puskesmas Pandanwangi, } \\
\text { Malang, this study using the approach of HBM theory and instrument. } \\
\text { Sampling was done through a purposive and accidental sampling method. } \\
\text { The data analysis was done through multivariate analysis, which used } \\
\text { multiple regression to determine the effecting factors based on the HBM } \\
\text { theory on the obedience of hypertensive patients during the } \\
\text { antihypertensive captopril and amlodipine medications therapy. Factors of } \\
\text { HBM theory that affect the obedience of hypertensive patients are self- } \\
\text { efficacy, perceived severity, and perceived barrier. Whereas, the } \\
\text { unaffected factor are perceived suspectibility and perceived } \\
\text { benefits. Overall, factors of HBM theory affect obedience. }\end{array}$ \\
\hline
\end{tabular}

\section{INTRODUCTION}

Hypertension, according to the World Health Organization (2013), is a condition in which blood vessels have high blood pressure (systolic blood pressure $\geq 140 \mathrm{mmHg}$ or diastolic blood pressure $\geq 90$ $\mathrm{mmHg}$ ) that persists. The latest statistics show that there were $24.7 \%$ of the population of Southeast Asia

This article is licensed under a Creative Commons Attribution 4.0 International License, which permits use, sharing, adaptation, distribution and reproduction in any medium or format, as long as you give appropriate credit to the original author(s) and the source, as described at http://creativecommons.org/licenses/by/4.0/. and $23.3 \%$ of the population of Indonesia aged 18 years and over had hypertension in 2014 (World Health Organization, 2015). During 2012-2014, hypertension was included in the top ten diseases, especially in 
Malang, with a total of 58,046 cases (Dinas Kesehatan Kota Malang, 2014).

Two therapies are done to treat hypertension, namely pharmacological therapy and nonpharmacological therapy (Berkowitz, 2013). The therapy of Pharmacology is using antihypertensive drugs in the treatment. The classes of antihypertensive drugs used are diuretics, alphablockers, beta-blockers, central effect analgesics, calcium antagonists, RAAS inhibitors (ACE-Inhibitors and AT-II Receptor-blockers), and vasodilators (Tjay \& Rahardja, 2015). In general, hypertensive patients use captopril (ACE-Inhibitor) and amlodipin (calcium antagonist).

Patient compliance is a significant factor in determining the success of therapy. Compliance and a good understanding in carrying out therapy can affect blood pressure and prevent complications (Kementrian Kesehatan Republik Indonesia, 2006). Many theories that have been used to study compliance behavior, including the Health Belief Model, the theory of reasoned action, the theory of planned behavior, and integrated behavioral. The Health Belief Model (HBM) are the most frequently used (Hayden, 2009). HBM is a theory of changes in health behavior and psychological models that are used to predict health behavior by focusing on the perceptions and beliefs of individuals about a disease (Priyoto, 2014). HBM theory itself in its development there are six constructs, namely, perceived susceptibility (risk or vulnerability), perceived severity (seriousness or severity), perceived benefits (value or usefulness), perceived barriers (obstacles), cues to Action (behavioral cues), and self-efficacy (individual motivation) (Conner \& Norman, 2005).

This study will be conducted at the Puskesmas (Central Public Health Center) Pandanwangi because the patient's prevalence of hypertension is quite high, at $10 \%$ of the total number of patients.

\section{RESEARCH METHOD}

This research was an observational analytic study with a cross-sectional approach. The instrument used was a questionnaire. The sampling method is a purposive and accidental sampling. Respondents were given a question questionnaire, which included a compliance questionnaire and the HBM. Then the data were analyzed by multivariate analysis using multiple regression tests in SPSS to determine the effect of the HBM factor on hypertension patient compliance in the use of captopril and amlodipine antihypertensive drugs.

\section{RESULTS AND DISCUSSION}

Based on the results of research on factors that influence the compliance of hypertension patients in the use of antihypertensive drugs captopril with the HBM theoretical approach in Puskemas Pandanwangi conducted in October 2017, the number of samples that met the inclusion criteria was 37 for captopril and 80 for amlodipine.

Distribution of respondents based on the HBM variable

Distribution of respondents based on the HBM variable in hypertensive patients undergoing treatment at the Puskesmas Pandanwangi using a Likert Scale questionnaire consisting of four alternative answers.

From the Likert scale, the maximum number of answers to the HBM questionnaire was found to be 68 . The number is derived from 17 question items. Each question has a maximum value of 4 . The independent variable with 3 question numbers will be a maximum of 12 , and those that have 4 question numbers will be 16 . Total the value of each question divided by the maximum total value of each independent variable multiplied by $100 \%$ so that the percentage of the number of questions is found.

The percentage results are categorized into 4, namely $76-100 \%$ (good), $56-75 \%$ (good enough), $40-55 \%$ (not good), and $<40 \%$ (not good). If the result has obtained the percentage results from each question number, then the next percentage calculation will be done per category of that percentage. The steps are, the frequency $(n)$ obtained per percentage category divided by the total number of respondents multiplied by $100 \%$, the percentage results obtained per category of the percentage of each independent variable (vulnerability, seriousness, benefits, obstacles, and confidence).

It was known (Table 1 and Table 2) that respondents who were categorized as good percentages (75 $100 \%$ ) are respondents who have a perception of self -confidence, seriousness, and obstacles to the hypertension. In comparison, respondents with perceptions of vulnerability and benefits of hypertension suffered in the category of percentage were quite good ( $56-75 \%$ ).

Influence test results and influence of each HBM variable on hypertension patients compliance in the use of antihypertensive drugs

The effect of each HBM variable on adherence can be tested using the T-test. The test of the influence of 
Table 1. Distribution of respondents using captopril based on HBM variable: vulnerability (1), seriousness (2), benefits (3), obstacles (4), and self-confidence (5).

\begin{tabular}{llllll}
\hline Category (\%) & \multicolumn{7}{l}{ HBM variable $(\mathbf{n})$} \\
\cline { 2 - 6 } & $\mathbf{1}$ & $\mathbf{2}$ & $\mathbf{3}$ & $\mathbf{4}$ & $\mathbf{5}$ \\
\hline $76-100$ & 6 & 20 & 4 & 20 & 26 \\
$56-75$ & 23 & 12 & 11 & 13 & 6 \\
$40-55$ & 6 & 3 & 11 & 3 & 5 \\
$<40$ & 2 & 2 & 11 & 1 & 0 \\
\hline
\end{tabular}

Table 2. Distribution of respondents using amlodipine based on HBM variable: vulnerability (1), seriousness (2), benefits (3), obstacles (4), and self-confidence (5).

\begin{tabular}{llllll}
\hline Category (\%) & \multicolumn{6}{l}{ HBM Variable (n) } \\
\cline { 2 - 6 } & $\mathbf{1}$ & $\mathbf{2}$ & $\mathbf{3}$ & $\mathbf{4}$ & $\mathbf{5}$ \\
\hline $76-100$ & 3 & 14 & 14 & 14 & 30 \\
$56-75$ & 55 & 15 & 24 & 44 & 16 \\
$40-55$ & 20 & 25 & 23 & 21 & 14 \\
$<40$ & 2 & 26 & 19 & 1 & 20 \\
\hline
\end{tabular}

Table 3. Influence test and the amount of influence of HBM variables with patient compliance in captopril.

\begin{tabular}{llll}
\hline Variable & Sig. & R Square & Significancy \\
\hline Vulnerability & 0,107 & 0,073 & Not Significant \\
Seriousness & 0,024 & 0,138 & Significant \\
Benefit & 0,228 & 0,041 & Not Significant \\
Obstacles & 0,05 & 0,207 & Significant \\
Self-Confidence & 0,000 & 0,761 & Significant \\
\hline
\end{tabular}

Table 4. Influence test and the amount of influence of HBM variables with patient compliance in amlodipine.

\begin{tabular}{llll}
\hline Variable & Sig. & R Square & Significancy \\
\hline Vulnerability & 0,278 & 0,015 & Not Significant \\
Seriousness & 0,05 & 0,121 & Significant \\
Benefit & 0,071 & 0,041 & Not Significant \\
Obstacles & 0,000 & 0,266 & Significant \\
Self-Confidence & 0,000 & 0,270 & Significant \\
\hline
\end{tabular}

the HBM variable (vulnerability, seriousness, benefits, obstacles, and self-confidence) on the compliance of hypertensive patients in the use of antihypertensive drugs captopril can be tested using the coefficient of determination test ( $R$ square).

Perceived susceptibility is the perception of perceived vulnerability to the risks that will arise from the disease. The effect of perceived susceptibility on the compliance of hypertensive patients has a significant value of 0.107 greater than 0.05 , and the magnitude of influence in explaining the compliance of hypertensive patients is 0.073 , which means that there is no influence between vulnerability and hypertension patient compliance. This study is following the research from Yue, Li, Weilin \& Bin (2015), which states that vulnerability influences adherence to taking antihypertensive drugs, and following the research from Purwanti \& Nurhayati (2017), which states that there is no influence between the perception of vulnerability and DM patient compliance in performing foot care.

Perceived severity is also the seriousness of a disease in an individual, family, or community that drives a person to seek treatment or prevention of the disease (Wawan, 2010). The effect of perceived severity on the adherence of hypertensive patients has a significant value of 0.024 less than 0.05 , and the magnitude of influence in explaining the adherence of hypertensive patients is 0.138 , which means that there is an influence between vulnerability and hypertension patient compliance. This study is following the research from Purwanti \& Nurhayati (2017), which states that there is an influence between the perception of seriousness and DM patient compliance in performing foot care. Perceived seriousness includes beliefs about the disease itself (for example, whether it is lifethreatening or can cause disability or illness) as well as the broader impact of the disease on work and social roles (Onoruoiza, Musa, Umar \& Kunle, 2015).

Perceived benefits are things that someone believes as a result of preventive measures. The perception of benefits is defined as the magnitude of the benefits or benefits derived from a preventive measure, the higher the chances of someone taking the preventive action (Hayden, 2014). The effect of perceived benefits on hypertension patient compliance has a significant value of 0.228 greater than 0.05 , and the magnitude of influence in explaining hypertension patient compliance is 0.041 , which means that there is no influence between the benefits of hypertensive patients adherence. This study shows that respondents believe that the efforts made in the treatment of hypertension patients do not provide benefits. In contrast to the research from Purwanti \& Nurhayati (2017), which stated that the perception of benefits has an influence on the patient's management in performing foot care. Purwono (2014) also found that there was a significant influence between the perception of benefits and the commitment to prevent tertiary hypertension.

Perceived barriers are negative things that a person believes are the result of preventive actions. The influence of perceived barrier (obstacle) on the compliance of hypertensive patients has a significant value of 0.05 equal to 0.05 , and the magnitude of the effect in explaining the compliance of hypertensive patients is 0.207 , which means that there is an influence between obstacles and hypertension patient compliance. This study is not following research from Purwanti \& Nurhayati 
(2017), which states that there is no influence between the perception of barriers to the ability of DM patients to do foot care. Perceived barriers to taking action include perceived discomfort, burden, danger (for example, side effects of medical procedures) and discomfort (for example, pain, emotional anger) involved in engaging in the behavior (Onoruoiza et al., 2015).

Self-efficacy is a person's belief in their ability to do things (Dellinger, Bobbett, Olivier \& Ellet, 2008). The effect of Self Efficacy on the compliance of hypertensive patients has a significant value of 0.000 less than 0.05 , and the magnitude of the influence in explaining the compliance of hypertensive patients is 0.761, which means that there is an influence between self-confidence and hypertension patient compliance, which shows that respondents believe that their efforts in the treatment of hypertension will produce results. This study is following research from Yue et al. (2015), which concluded that selfefficacy is related to adherence to taking antihypertensive medication. Mulyati, Yetti \& Sukmarini (2013) also stated that there is an influence between self-efficacy and Self Management Behavior (SMB) in hypertensive patients.

From this study, the HBM (X) value of the compliance variable $(\mathrm{Y})$ as a whole, both captopril and amlodipine were 0.000 , which shows that the HBM (X) factor significantly influences the patient compliance variable in the use of captopril $(\mathrm{Y})$ with an $\mathrm{R}$ square value of 0.791 which means $79.1 \%$ compliance can be explained by all HBM variable. In contrast, while the rest is influenced by variables others that are not researched. Meanwhile, patient compliance in using amlodipine $(\mathrm{Y})$ with an $\mathrm{R}$ square value of 0.279

\section{CONCLUSION}

Factors that influence the compliance of hypertensive patients in the use of antihypertensive drugs in the Puskesmas Pandanwangi with the HBM theory approach are confidence (self-efficacy), seriousness (perceived severity), and obstacles (perceived barriers). At the same time, those that do not affect are vulnerability (perceived susceptibility) and benefits (perceived benefits). While overall factors that influence the compliance of hypertensive patients in the use of antihypertensive drugs in Puskesmas Pandanwangi with the HBM approach show, that affects significantly.

\section{REFERENCES}

Conner, M., \& Norman, P. (2005). Predicting Health Behaviour. London, UK: McGraw-Hill Education.

Ministry of Health. (2006). Pharmaceutical Care untuk Penyakit Hipertensi. Jakarta, Indonesia: Authors.

Dinas Kesehatan Kota Malang. (2014). Profil Kesehatan Kota Malang Tahun 2014. Malang, Indonesia: Authors.

Hayden, J. 2014. Introduction to health behavior theory. Jones and Bartlett Publisher. Canada.

Berkowitz, A. (2013). Patofisiologi Klinik. Tangerang, Indonesia: Binarupa Aksara.

Dellinger, A. B., Bobbett, J. J., Olivier, D. F., \& Ellett, C. D. (2008). Measuring teachers' self-efficacy beliefs: Development and use of the TEBS-Self. Teaching and teacher education, 24(3), 751766.

Purwanti, L. E., \& Nurhayati, T. (2017). Analisis faktor dominan yang mempengaruhi kepatuhan pasien DM tipe 2 dalam melakukan perawatan kaki. Journal of Health Sciences, 10(1), 44-52.

Mulyati, L., Yetti, K., \& Sukmarini, L. (2013). Analisis Faktor yang Memengaruhi Self Management Behaviour pada Pasien Hipertensi. Jurnal keperawatan padjadjaran, 1(2).

Wawan, A. (2010). Teori \& Pengukuran Pengetahuan, Sikap, dan Perilaku Manusia. Yogyakarta, Indonesia: Nuha Medika.

Onoruoiza, S. I., Musa, A., Umar, B. D., \& Kunle, Y. S. (2015). Using health beliefs model as an intervention to non compliance with hypertension information among hypertensive patient. IOSR Journal of Humanities and Social Science, 20(9), 11-16.

Priyoto. (2014). Teori Sikap dan Perilaku dalam Kesehatan. Yogyakarta, Indonesia: Nuha Medika.

Purwono, J. (2014). Faktor-Faktor Yang Berhubungan Dengan Komitmen Pencegahan Tersier Penyakit Hiper-tensi Pada Masyarakat Di Wilayah Kerja Puskesmas Kota Metro Tahun 2014. Jurnal Keperawatan Aisyiyah, 1(2).

Tjay, T. H., \& Rahardja, K. (2015). Obat-Obat Penting (Khasiat, Penggunaan, Efek-Efek Sampingnya), 
Edisi ke-7, Jakarta, Indonesia: PT Elex Media Komputindo.

World Health Organization. (2013). A Global Brief on Hypertention. Geneva, Switzerland: Authors.

World Health Organization. (2015). Global Tuberculosis Report 2015. Geneva, Switzerland: Authors.

Yue, Z., Li, C., Weilin, Q., \& Bin, W. (2015). Application of the health belief model to improve the understanding of antihypertensive medication adherence among Chinese patients. Patient education and counseling, 98(5), 669-673. 